\title{
Grundtvig and the Descent into Hell
}

The following special section on Grundtvig's poem I Kveld blev der banket paa Helvedes Port [This Night came a Knocking on Hell's Fortress-Gate] includes a new unrhymed metrical English translation of the poem with select commentary by S.A.J. Bradley, followed by two articles, the first by K.E. Bugge about the genesis of the poem and the Descent theme in Grundtvig's thinking; and the second by S.A.J. Bradley concerning the Anglo-Saxon poems which Grundtvig indicates were his inspiration to I Kveld and a small cluster of other hymns which he wrote for the Danish Church.

The editors 


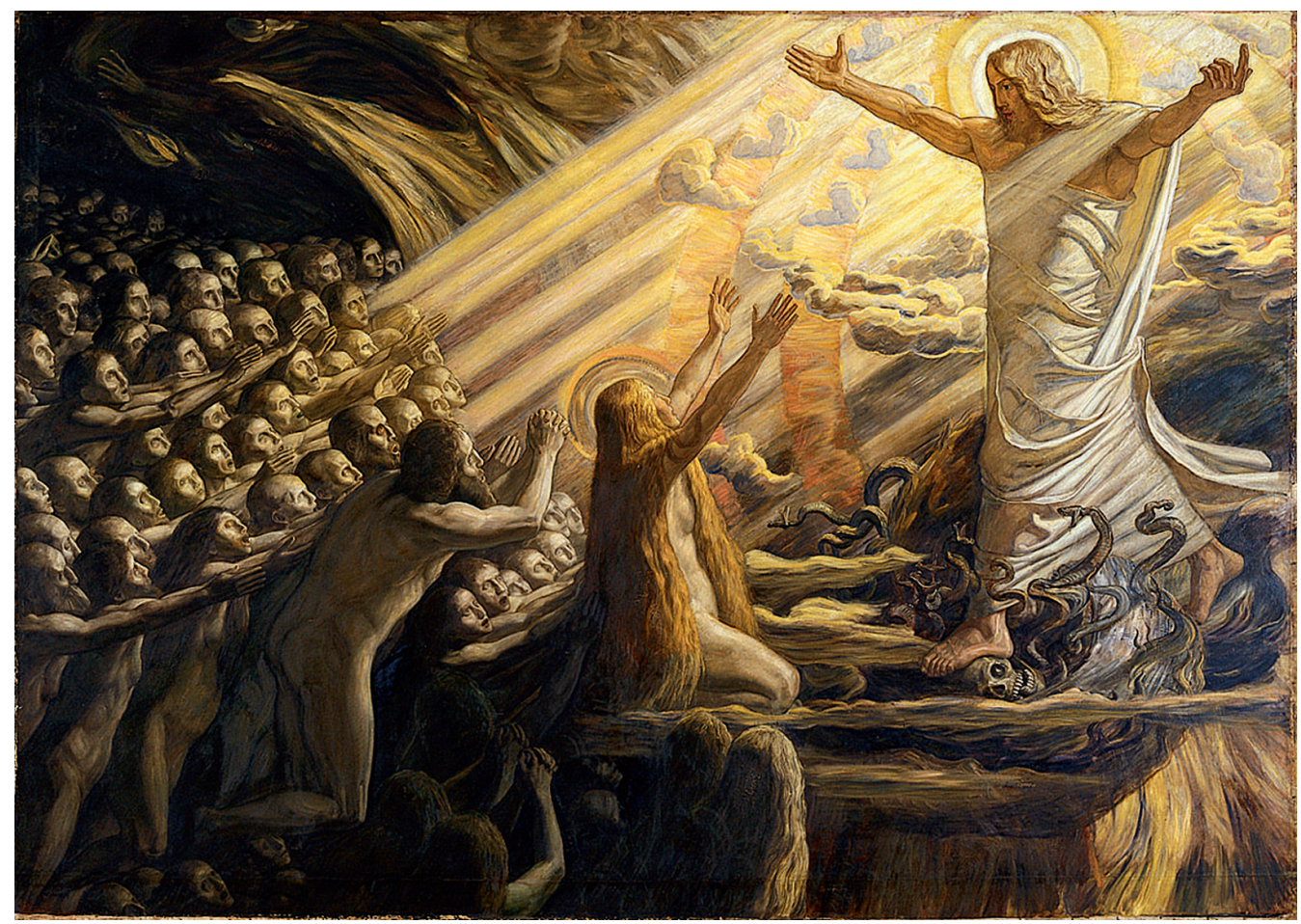

Oil-painting by Joakim Skovgaard (1856-1933). The National Gallery of Denmark. Painted 1891-94. Dimensions 3,5 $55 \mathrm{~m}$. Reproduced by courtesy of The National Gallery. 


\section{N.F.S. Grundtvig: \\ This night came a knocking on \\ Hell's fortress-gate}

1. This night came a knocking on Hell's fortress-gate as rumbles the thunder-roll's clamour.

The herald was mighty, momentous his news, so all in the underworld listened!

2. "From Heaven I warn now the vermin of Hell: from Earth there descends here a warrior. At dawn he shall leap the engulfing abyss all grief to soothe, even in Hades!

3. "Hot coals he shall tread as a maid treads her floor, and trample down lizards and dragons; the venomous Serpent he'll crush, and Hell's Wolf he'll chain, while the depths ring with roaring!"

4. At once on their elbows each captive sat up.

The demons were helpless to hinder:

like tempests they howled in the deep dark of night, belching rage, like to fire-spewing mountains!

5. At once on their elbows each captive sat up here in Hell had they never yet listened, but waited and watched both by day and by night, nor heeded the fire-dragons' venom!

6. And on the third day, when Hel-Cockerel crowed, and home came all earth-haunting spirits, then streamed forth in Hell Heaven-Kingdom's bright Sun: none had seen, even dreaming, its likeness!
I Kveld blev der banket paa Helvedes Port Saa dundrer den rullende Torden, Herolden var stærk, og Hans Budskab fuldstort, Thi lyttede Alt under Jorden!

Fra Himlen jeg melder nu Helvedes Kryb: Fra Jorden nedstiger en Kæmpe, Han springer i Gry over svælgende Dyb, For Graad selv i Helved at dæmpe!

Han vandrer paa Gløder som Jomfru paa Gulv, Han tramper paa Øgler og Drager, Hug-Ormen Han knuser, og Helvedes Ulv Han binder, mens Afgrunden brager!

Paa Albu sig reiste hver Fange saa brat, Det kunde ei Djævle afværge, Som Storme de hyled i bælgmørke Nat, Og fnøs som ildsprudende Bjerge!

Paa Albu sig reiste hver Fange saa brat Ei før blev i Helvede lyttet, De lured om Dag, og de lured om Nat, De ændsed ei Ilddrage-Spyttet!

Og Tredie-Dagen, da Hel-Hanen goel, Og Gienfærd kom alle tilbage,

Da skinned i Helvede Himmerigs Soel, I Drømme slet ingen saae Mage! 
7. And white as the clouds with a pale throng of stars went angels ahead of the Bold One, and as the sun, steep He rose up from the deep with clouds for a shield, rosy-gilded.

8. Through Hell then the splendour of God's glory streamed and gilded the swarthy-black devils -

but the walls split apart in the dance of its beams, the gates of Hell flew from their hinges!

9. At once now the captives all raised themselves up, but only to bow, deeply kneeling; and "Welcome, O blest One, our Saviour-Man!" then resounded from souls without number!

10. Now, "Adam, where are you?" was heard, in a voice like a lark on some Whitsunday morning. Then solace eternal was born there in Hell: the grief that was Man's met with healing!

11. Then Eve made to speak, to the Saviour drew near, and said "O my Son and my Master! I caused it, I only, that here we all lie, for I yielded, alas, to deception!

12. "That Serpent which even now writhes in the flames had coiled round the Knowledge-Tree's branches. It glittered like gold, put the thought in my mind that we ruled the world, and we only!

13. “'You might rule over sky, you might rule over earth' the flattering voice whispered to me: but pallid and blue into Hell we have passed, far different was what we encountered!
Som Skyerne hvide med Stjerne-Hob bleg,

Gik Englene foran den Bolde,

Og brat som en Soel Han fra Dybet opsteg,

Med guldrøde Skyer til Skjolde.

I Helvede skinned Guds Herligheds Glands, Guldfarved de Djævle kulsorte,

Men Murene revned for Straaler i Dands, Af Hængsel fløi Helvedes Porte!

Sig reiste de Fanger nu alle paa Stand, Men dog kun for dybt at nedknæle, Velkommen, velsignet, vor Frelser-Mand! Det lød fra utallige Sjæle!

$\mathrm{Nu}$ “Adam, hvor er du?" blev hørt med en Røst, Som Lærkens en Pindsedags-Morgen, Da fødtes i Helved den evige Trøst, Sin Hel-Sot fik Menneske-Sorgen!

Da Eva tog Ordet, gik Frelseren nær, Og sagde: min Søn og min Herre! Jeg ene det voldte, at vi ligge her, For jeg lod mig daare, desværre!

Den Slange, som krymper i Flammer sig nu, Sig bugted om Kløgt-Træets Grene, Den glimred som Guld, og den skiød mig i Hu: Vi raadte for Verden alene!

I raade for Himmel, I raade for Jord, Saa hvisked den smigrende Stemme; Da blege og blaa vi til Helvede foer, Langt andet vi fik at fornemme! 
14. "If you are that seed promised me for a cure, conceived and brought forth of a woman, not in vain shall your Mother now fall at your feet; not, fear-sick, be left here abandoned!"

15. From her mild sun-bright eyes now two tears trickled down and - wondrous it was to behold it with beautiful colours, in form as a crown, round Eve there was fashioned a rainbow!

16. God's Majesty's Glory his Mother then kissed the dead all looked on in great wonder and up, like a queen, with a rainbow-wreath, stood lovely Eve, who repented her error!

17. Then deeper by ten times a thousand miles down sank the devils, while Eve moved on upwards; nor dared they to howl, but they bit on their lips and trembled so Earth was set quaking!

18. From Hell he ascended now, this Lord so bold, and with him so fair a throng followed.

As the sun upon clouds he was set on a shield: aloft all the Prophets then bore him!

19. Now triumph there was where once weeping was heard. In Hell Death alone stayed, bewildered. The cherub threw open the closely-sealed door; in the dust the armed watch fell prostrated!

20. Majestical thus, on the third day uprose our guiltless yet crucified Saviour; thus we upon earth now confess it as Truth: God's Son has once sojourned in Hades!
Men est Du den Sæd, mig blev loved til Bod, Undfanget og født af en Kvinde, Da falder ei Moder omsonst Dig til Fod, Forlades ei grusom herinde!

Fra Soel-Øine milde to Taarer nu faldt, Og underfuldt var det at skue, Med deilige Farver i Krone-Gestalt Sig danned om Eva en Bue!

Saa kyssed sin Moder Guds Herligheds Glands Til Under for alle de Døde,

Og op stod, som Dronning, med Regnbue-Krands Skiøn Eva, som angred sin Brøde.

Titusinde Mile end dybere ned Sank Djævle, da Eva sig hæved, De turde ei hyle, i Læbe sig beed, Og sittred, saa Jorderig bæved!

Fra Helvede steg nu den Herre saa bold, Ham fulgde saa faver en Skare, Som Solen paa Skyer, Han sattes paa Skjold, Propheterne alle Ham bare!

Triumph blev der nu, hvor kun Graad hørdes før, Kun Død sad i Helved bedrøvet, Cheruben oplod den forseiglede Dør, Skjold-Vagten sig kasted i Støvet!

Saa herlig opstod paa den tredie Dag Vor Frelser, uskyldig korsfæstet, Thi er det paa Jord nu en Saligheds-Sag: Guds Søn haver Helvede giæstet! ${ }^{1}$

1 Sang-Verk til den Danske Kirke (GSV) I (1944), 471-74. 


\section{NOTES}

v. 1 This night: The Danish phrase $i$ kveld can mean "in the evening" or "on this evening, tonight." If Grundtvig had in mind a traditional liturgical context and use for this text, the phrase would be the (presumably deliberate) equivalent of the Latin phrase In hac nocte [On this night] or Hac nox est [This is the night] - as in the Exsultet: Hac nox est, in qua, destructis vinculis mortis, Christus ab inferis victor ascendit [This is the night on which, the shackles of death having been destroyed, Christ ascended as victor from the underworld] (see further Bradley's article below). This formula was, and is, used where the Church emphasises the present immediacy of a past event of Scriptural history commemorated on that day, or the eve of that day, in the Church's calendar. The liturgical treatment of the narrative of Christ's descent into Hell is historically part of the dramatic ceremonies of the Vigil of Easter on the Saturday night, eve of Easter Sunday, which included the singing of the Exsultet. This context and its possible relevance to an understanding of Grundtvig's conceptualisation of I Kveld is discussed further in Bradley, below.

The herald: Grundtvig does not name the herald, but the use of a capital letter for the pronoun "Hans" ("Hans Budskab," v.1, line 3) may indicate that the speaker is Christ himself. This would be to follow the tradition of the later Latin version of The Gospel of Nicodemus where the voice is categorically Christ's own. There the supposed eye-witness narrator, Karinus, says: "[...] suddenly there shone upon us a great light, and Hades and the gates of death trembled. And the voice of the Son of the Father most High was heard, as the sound of loud thunder, and crying out most mightily, it thus exclaimed: $\mathrm{O}$ ye princes, throw back your gates, lift up the eternal gates; the King of Glory, Christ the Lord, approacheth to enter" (tr. Cowper 1867, 377). The voice is, of course, invoking the momentous and prefigurative bidding of Psalm 24:7-10. However, the earlier Latin Gospel of Nicodemus, Part II, ch. v, atrributes the cry to angels: "And while Satan the prince, and Hades were talking thus together, there was suddenly a sound as of thunder and a crying of spirits: Lift up your gates, ye princes, and be ye lift up, ye everlasting doors, and the King of Glory shall come in" (tr. Cowper 1867, 354). [In conversations, Professor Bugge notes that the Danish literary critic Hans Brix (Brix 1912, 33) suggested the herald is an archangel.] Similarly, in Grundtvig's AngloSaxon source the bursting of the gates is accompanied by the clamorous voices of angels. First the Anglo-Saxon poet mentions a general din: Pa him egsa becom, / dyne for deman, / pa he duru in helle / brac and begde [Then a terror befell them, the din caused by the Judge when he burst and crushed the gates of Hell] (Christ and Satan, 378-80). A few lines further on the poet refers again to the "din" - this

1 References to Bugge in these notes are to K.E. Bugge's contributions in the published article below or to oral communications arising from the collaborative preparation of our respective contributions. All texts cited are listed at the end of Bradley's article. 
time clearly specifying that it involves angels: Pa com engla sweg, / dyne on dagred [Then came the voice of angels, a din in the dawning day]. Thus, the Anglo-Saxon poet seems to be following the tradition of the earlier Gospel of Nicodemus. Henry Larsen's speculation (Larsen 1903, 34) that the herald is John the Baptist was perhaps inspired by the fact that in the Anglo-Saxon poem, as in the Gospel of Nicodemus, John does appear (along with other Biblical figures) in his Scriptural role as the voice in the wilderness - now the wilderness of Hell - crying the promised coming of the Lord: but would Grundtvig - could Grundtvig - have relied upon his congregation to supply this particular identity to an unnamed "herold"? See the following articles for further discussion of the role of John within Hell.

v. 2 At dawn: Hell, of course, has its own darkness, into which Christ enters in a blaze of light; but in terms of earthly time also, darkness is about to yield to light - the darkness of that sabbath night to the glory of the dawn of Easter Day. About this, the Anglo-Saxon poet is very particular: pis was on uhtan eall geworden / ær dagrede [This all happened in the darkness before the dawn] (Christ and Satan, 46364), that is, ær on morgen pæs pe dribten god of deaðe aras [before the morning-time in which the Lord God arose from death] (Christ and Satan, 513-14). Doubtless, the poet's insistence on this time-sequence reflects not only the tradition embodied in the Gospel of Nicodemus but also the liturgical prescriptions of the Anglo-Saxon Church for the Easter Vigil on Holy Saturday: by a tradition still maintained in churches where the Vigil is kept, it must begin after nightfall and end before dawn. In both the Anglo-Saxon poet's and Grundtvig's narratives, between the Harrowing of Hell and the Resurrection, Christ leads the liberated souls up to heaven.

he shall leap: Here, it is likely that Grundtvig is consciously asserting consistency with his Ascension-hymn, Himmel-Farten saae i Løn / Salomon, Kong Davids Søn [Solomon, King David's son, / Christ's Ascension saw, foreshown]. His source for that hymn was a poem on the ancient topos of Christ's 'leaps' composed by the Anglo-Saxon Cynewulf, which Grundtvig had encountered in the Exeter Book (discussed more fully in the following articles).

v. 3 dragons: It seems unlikely that Grundtvig would not have Nordic dragons in his imagination here: but the dragons are in the Anglo-Saxon source, where they fairly certainly derive from early medieval Christian tradition in art and literature: Ace at helle duru dracan eardigad, / hate on redre [Ever at Hell's doors dragons dwell, hot at their heart] (Christ and Satan, 97-8). That Christian tradition draws, of course, upon Scriptural allusions to dragons, chiefly in the Old Testament but also, notably, in the eschatological context of the Book of Revelation.

the venomous Serpent he'll crush: Reference to the serpent must immediately prompt recall of God's words of condemnation upon the serpent at the Fall (Genesis 3:15; NIV): "And I will put enmity between you and the woman, and between your offspring and hers; he will crush your head, and you will strike his heel." But 
the whole stanza, particular in lines 2-4, recalls the assurances of Psalm 91: You will trample the great lion and the serpent (Psalm 91:13; NIV). In v. 12 Grundtvig explicitly identifies this Serpent with the one which deceived Eve in the Garden.

Hell's Wolf: In the sequence of lyrics in the Exeter Book known as Christ I or The Advent Lyrics, Grundtvig met the phrase se awyrgda wulf [the accursed wolf] (Christ I, 256), meaning Satan and echoing Scriptural imagery in, for example, John 10:12. However, it is not implausible that Grundtvig is here calculatedly associating Christian imagery with imagery in the Norse mythological tradition, centred upon the Fenris Wolf (Fenrisúlfr) and Ragnarök.

v. 4 on their elbows: This curious image of prostrate people propping themselves up on their elbows replicates the Anglo-Saxon of the source: Aras pa anra gehwylc, and wið earm gesat, / hleonade wið handa [Then each one rose up and propped themselves on their arm and leaned upon their hands] (Christ and Satan, 430).

fire-spewing mountains: It is possible that Grundtvig has in mind the ancient tradition that certain volcanoes - such as Hekla in Iceland and Vesuvius in the Gulf of Naples - were portals into Hell. The image of demons spewing fire may have been suggested by the Anglo-Saxon poet, who says of Satan that when he raged against losing his place in heaven Word spearcum fleah / attre gelicost [His speech flew in sparks, most like to venom] (Christ and Satan, 161-62).

v. 5 waited and watched: In so far as Grundtvig's verb lured can imply waiting and watching in expectancy, it raises a question as to what the expectancy of these souls in Hell could have been - in Grundtvig's view. Bugge - citing Benedikt Otzen, Den antike jødedom $(1984,182)$ - suggests that, in accordance with Jewish apocalyptic ideas from the time of Christ, Grundtvig might have envisaged these souls as expecting that there would come a re-creation of the world and of humankind - that all should once more be as it was when it was first shaped by the Creator's hand. In the Exeter Book (Christ I, 138-40), known to Grundtvig, an ambiguous (and unScriptural) prophecy of a Redeemer-figure who would not only visit the earth but would also journey down to the depths is revealed by "the renowned Melchisedech, wise in spirit," when he met with Abram (Genesis 14:18). Further possibilities and probabilities are discussed in Bradley, below.

v. 6 third day ... Hel-Cockerel: The third day is of course Easter Morning. As the traditional liturgical rubrics insist, dawn had not yet broken in the world - but in the underworld a new dawn was dramatically breaking as Heaven-Kingdom's bright Sun streamed forth its light into Hell. Grundtvig here merges Norse myth with the Christian apocryphal narrative. In the Edda-poem Völuspá, v.43, the cock Gullinkambi, among the gods, and another "soot-red" cock at the gates of Hel (the underworld or realm of the dead in Norse myth), crow to signal the imminence of the great battle of Ragnarök. 
home came all earth-haunting spirits (Gienfærd kom alle tilbage): Like other colourful details not found in the Anglo-Saxon source nor in the Gospel of Nicodemus, this reference to genferd [ghosts, revenants] seems to owe more to folklore or myth than to Christian orthodoxy. However, Grundtvig is in company with Shakespeare: "I am thy father's spirit, / Doomed for a certain term to walk the night / And for the day confined to fast in fires" (Hamlet, Act I, Scene 5). "Tis now the very witching time of night, / When churchyards yawn and hell itself breathes out / Contagion to this world" (Hamlet, Act 3, Scene 2). Professor Bugge has also drawn to my attention Grundtvig's Gienferdet [the revenant], one of the ballads in his Danske Kampeviser til Skole-Brug [Danish ballads for use in schools] (Copenhagen 1847, 181-85): "Men nu galer Hanen den sorte, / Nu aabner sig Helvedes Porte. // Og nu galer Hanen den røde, / Til graven skal alle de Døde." [But now crows the black cock, now open the gates of Hell. And now crows the red cock. To the grave all the dead must return]. Professor Bugge also observes that in his Nyaarsmorgen (1824), vv. 278-85 [US IV, 333-35] Grundtvig thanks his old nurse Malene most heartily as his Sprogmesterinde (language-teacher), for teaching him the language of the common people - and much superstitious folklore besides (see Grundtvig 1925, 127).

v. 8 the splendour of God's glory (Guds Herligheds Glans): Grundtvig may here (as in v.6, line 3) have in mind the account of the Transfiguration of Christ, particularly in Luke's gospel (especially Luke 9:32); or that glory of the New Covenant (sealed by Christ on the Cross) of which Paul writes in 2 Corinthians 4:6 - a glory far surpassing that of the Law which Moses brought down from Mount Sinai. Exodus 33:18 records that Moses said to the Lord: "Now show me your glory." When he subsequently descended from Sinai his face, which had gazed upon the Lord's glory, was too radiant for the people to look upon.

gilded the swarthy-black devils: Bugge notes that this juxtapositing of light and dark, gold and black, matches an image in Thomas Kingo's hymn (1689) on the resurrection of Christ on Easter morning. "Som dend Gyldne Sool frembryder / Giennem dend kulsorte Sky" [As the golden sun breaks forth through the coalblack murk] (KSS IV, 513; now DDS 227).

flew from their hinges: The broken gates of Hell are a standard component in traditional pictorial representation of the Harrowing of Hell.

v. 10 Adam, where are you?: Grundtvig's deliberate echo of God's summons to Adam who was hiding after tasting the forbidden fruit (Genesis 3:9). Grundtvig, in the spirit of the medieval exegetes, was alert to the rich significations of reversals and symmetries within the divine providential narrative.

Whitsunday morning: Whitsunday (Danish Pinsedag), the seventh Sunday after Easter, the festival day of Pentecost, marks the descent of the Holy Spirit and the 
birthday of the Christian Church. From early on, it has been a favoured time for baptism. Spring is well arrived in the northern hemisphere. The lark is singing high over its nest. It is traditionally a day of festivity, both ecclesiastical and secular. Does an image exist more Danish than this, of the lark rising in song into the morning sky on Pinsedag?

v. 11 my Son: Eve, "our credulous mother" (John Milton, Paradise Lost, Bk. IX, 644), from whom, in the Biblical account, all humanity descends, might call any male, symbolically, her son. But here Grundtvig appears again to adopt the ancient model of symmetry-and-reversal within the divine providential narrative, in which Mary is viewed as the Second Eve, just as Jesus is viewed as the New, or Second, Adam. In this sense, the disobedient First Eve can plead the merits and the motherhood of the obedient Second Eve (Mary), and call Christ 'my Son'. Note also "your Mother" in v.14 and "his Mother" (affirming, as it were, Christ's acceptance of Eve's appeal in virtue of Mary's motherhood) in v.16.

I caused it, I only: Bugge points to 1 Timothy 2:14 - "And Adam was not the one deceived; it was the woman who was deceived and became a sinner" (NIV). But see further discussion of Eve's guilt in Bradley, below.

v. 13 pallid and blue: Bugge notes that bleg (pale, pallid) is the colour of the human body; bla (blue), according to northern myth is one of the colours of the goddess of death, in so far as she combines blue-black with human colouring.

v. 14 seed promised me for a cure: Genesis 3:15 - "And I will put enmity between thee and the woman, and between thy seed and her seed; it shall bruise thy head, and thou shalt bruise his heel" (The Holy Bible, King James Version (the Authorized Version; first published 1611)).

Not, fear-sick, be left here abandoned! (Forlades ei grusom herinde!): The uninflected form of grusom suggests that it is intended as an adjective qualifying Moder (line 3) with a meaning (now archaic) equivalent to the phrase " $i$ gru" - in a state of acute distress, sick with fear. Cp. Grundtvig: "Se Marie Magdalene! / Hænder nys hun vred i Gru" [See, Mary Magdalene! she was but now wringing her hands in distress] (GSVI, 555).

v. 15 tears: If, in adding this detail of Eve's two tears, Grundtvig has in mind Norse myth, two goddesses, Freyja and Frigg, could lend associations which both enhance his representation of Eve and promote his conviction that deep-lying correspondences exist between the Norse and the Christian mythos. Freya is a goddess of fertility who weeps for the absence of her husband. Her tears turn to red gold or amber. Snorri Sturluson, in the 13th c. Skáldskaparmál, records that the poetic name for 'gold' is 'Freyja's weeping'. In Snorri's Prose Edda, when Frigg's son, Baldr, is killed and goes to the underworld ( $\mathrm{Hel})$, she wins a pledge that if all 
creation will weep for Baldr he will be released. All created things weep - except one giantess who is probably the malevolent Loki in disguise. So Baldr will remain in Hel until Ragnarök when he will emerge to rule over a recreated and peaceful world. But tears also have an ancient place in Christian spirituality. John 11:35-6 - "Jesus wept. Then said the Jews, Behold how he loved him!" In penitential context (familiar to the Anglo-Saxon religious poets) Christian weeping is an external sign of compunctio cordis - a piercing of the heart by remorse and repentance which, when true, wins the consolation of God's grace. Still in Grundtvig's day, weeping among the congregation, even in the pastor himself, was, if true, held to be a sign of heartfelt remorse and penitence for waywardness, and gratitude for God's mercies, not mere emotionalism or svermeri (see for example, Bradley 2008, item 35, p.103 and endnote 5). In Kvinde-Evangeliet (1842) Grundtvig invokes "Taare-Bakke" [streams of tears of remorse] at the idea of a Church devoid of women. Eve's two tears are symbolic, rather than literal. Bugge draws attention to GSVI, 555 and especially the poem to his daughter Meta (1844), US IX, 42-44.

It is worth giving one more example illustrative of the traditional significance of tears in Grundtvig's own experiencing and describing of the inner spiritual life. In an often emotional poem Til Sibbern [To Sibbern - F. C. Sibbern, a fellow student and lifelong friend], Grundtvig recalls his recent experiencing of the ritual of ordination to the priesthood.

Der Brødrene udrakte højre Haand,

For det med Suk af Herren at begiære,

At Kjærligheds og Krafts og Sandheds Aand

Miskundelig paa mig neddale vilde,

Da aabnede sig Hjærtets Taarekilde,

Da sprængte Sjælen sine Fængselsbaand;

Og der jeg hørte Brødrene tilsammen

I Jesu Kristi Navn at sige Amen,

Da blev det samme i mit Bryst udtonet,

Og jeg mig følte med min Gud forsonet (PS I, 326).

[When the brethren [his brother-pastors] outstretched the right hand so as, with sighs, to beseech the Lord that the Spirit of love and strength and truth would mercifully descend upon me, then the tear-fount of the heart opened itself, then the soul burst its prison bonds; and when I heard the brethren say together in the name of Jesus Christ Amen, then the same was sounded forth in my breast - and I felt myself reconciled with my God.]

What a modern readership might regard (and perhaps some of Grundtvig's contemporaries did regard) as cloying emotionalism, many a predecessor of Grundt- 
vig, both after and before the Reformation, including the Anglo-Saxon poets and writers Grundtvig got to know, would have instantly recognised this as a classic and precise description of the process of "compunction of the heart" - the outward and highly esteemed manifestation of a great grace inwardly received and felt. This is Eve's experiencing, and the poetically symbolic tears are there to attest to the profound grace by which she is reconciled with her God.

v. 19 triumph where once weeping was heard: Grundtvig's literary device here, encapsulating reversal, is as old as the ancient Greek dramatic concept of peripeteia, reversal. It is memorably (that is, memorisably) used in the Psalms, for example in Psalm 30:5 - "Weeping may endure for a night, but joy cometh in the morning" (KJV) and in Psalm 126:5-6 - "They that sow in tears shall reap in joy. He that goeth forth and weepeth, bearing precious seed, shall doubtless come again with rejoicing, bringing his sheaves with him" (KJV). Christian writers through the centuries have made use of it, as expressing the capacity of God to intervene in human circumstances, transforming sorrow into joy, defeat into victory - or the reverse. The Anglo-Saxon poets liked the device - a superb example forms the opening 22 lines of The Descent into Hell in the Exeter Book, where the grief and weeping of the Marys' going early to the tomb of Jesus is transformed into the joy and triumph of the tidings of Christ's resurrection. Grundtvig appeals to the same moment of transformation and its imagery in lines 21-2 of Tag det sorte Kors fra Graven! (Sangvark til den danske Kirke I (1837; I, nr. 302)) where Mary Magdalene's weeping yields to joy upon encountering the risen Christ at the tomb on Easter morning: Se, af Øiets Taare-Flod/Morgen-Solen mildt opstod! [See, from the eye's tear-flood the morning sun gently arose]. See also the note on v.15.

the cherub: By this detail, Grundtvig incorporates allusion to another pattern of glorious reversal in the narrative of Providential history. After the Lord God expelled Adam and Eve, "he placed on the east side of the Garden of Eden cherubim and a flaming sword flashing back and forth to guard the way to the tree of life" (Genesis 3: 24; NIV). Now a cherub is sent to throw open the tomb from which Christ comes forth as victor over sin and death.

the closely-sealed door: Matthew 27:66 records that the chief priests and Pharisees, fearing that the followers of Jesus might steal the corpse overnight and then pretend it had risen from the dead, placed a seal and an armed guard upon the tomb.

v. 20 confess it as Truth: Professor Bugge has saved me from error by pointing out that, in Saligheds-Sag, Grundtvig is polemically insisting - against the consensus of theologians identified with the Enlightenment - that the descent into Hell is not a myth but a truth, and one which whosoever wishes to be saved must believe and confess, and that therefore its place as an article in the Apostles' Creed must be preserved. 



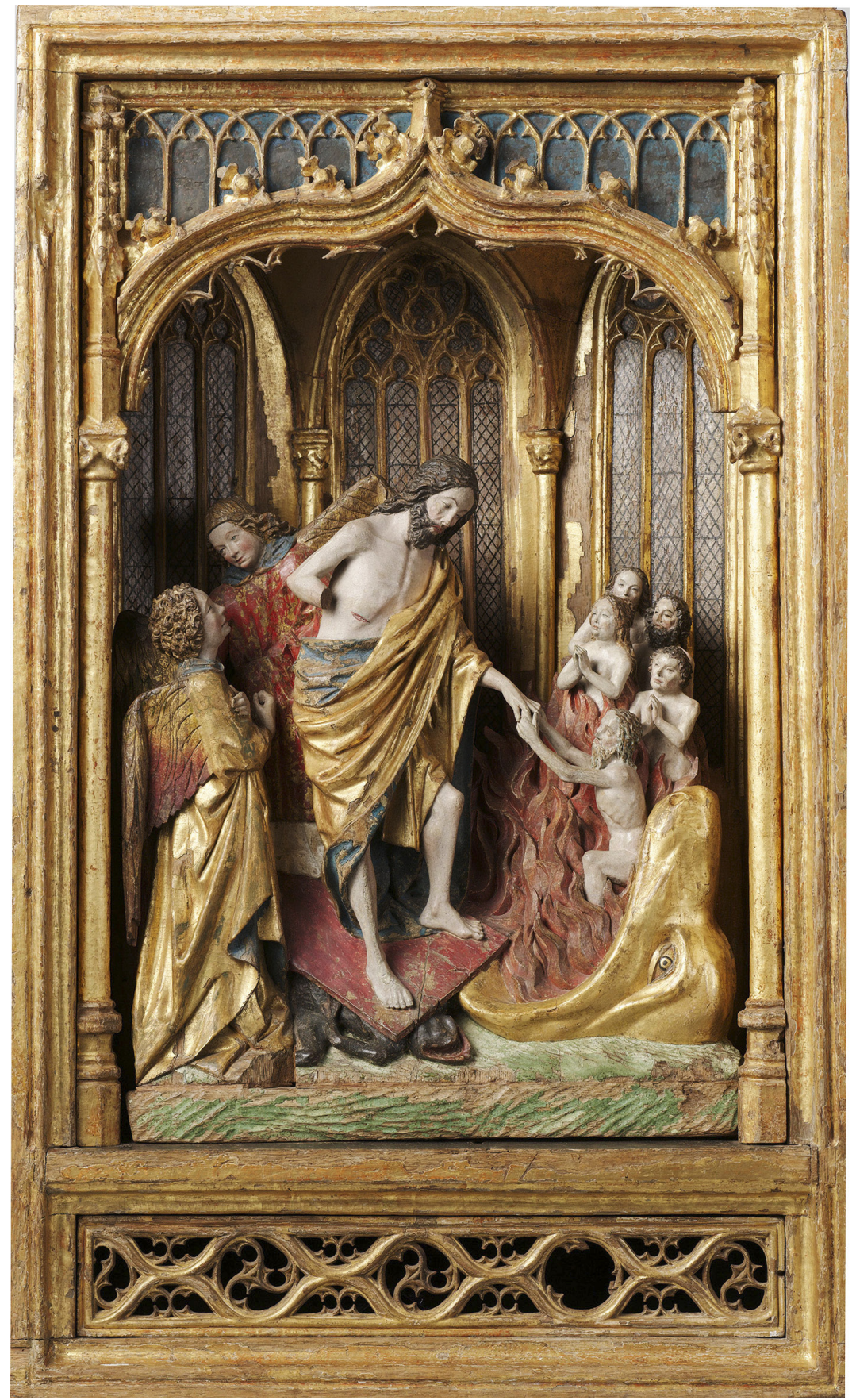

Painted oak carving (c 1460), Rijksmuseum Amsterdam. Artist unknown. Reproduced by courtesy of the Rijksmuseum. 